\title{
Leveraging Benefits Attributable to Centers within the Industrial Assessment Center Program
}

February 2002

Michaela Martin

Bruce Tonn

Susan Schexnayder 


\title{
DOCUMENT AVAILABILITY
}

Reports produced after January 1, 1996, are generally available free via the U.S. Department of Energy (DOE) Information Bridge:

Web site: http://www.osti.gov/bridge

Reports produced before January 1, 1996, may be purchased by members of the public from the following source:

\author{
National Technical Information Service \\ 5285 Port Royal Road \\ Springfield, VA 22161 \\ Telephone: 703-605-6000 (1-800-553-6847) \\ TDD: 703-487-4639 \\ Fax: 703-605-6900 \\ E-mail: info@ntis.fedworld.gov \\ Web site: http://www.ntis.gov/support/ordernowabout.htm
}

Reports are available to DOE employees, DOE contractors, Energy Technology Data Exchange (ETDE) representatives, and International Nuclear Information System (INIS) representatives from the following source:

Office of Scientific and Technical Information

P.O. Box 62

Oak Ridge, TN 37831

Telephone: 865-576-8401

Fax: 865-576-5728

E-mail: reports@adonis.osti.gov

Web site: http://www.osti.gov/contact.html

This report was prepared as an account of work sponsored by an agency of the United States government. Neither the United States government nor any agency thereof, nor any of their employees, makes any warranty, express or implied, or assumes any legal liability or responsibility for the accuracy, completeness, or usefulness of any information, apparatus, product, or process disclosed, or represents that its use would not infringe privately owned rights. Reference herein to any specific commercial product, process, or service by trade name, trademark, manufacturer, or otherwise, does not necessarily constitute or imply its endorsement, recommendation, or favoring by the United States government or any agency thereof. The views and opinions of authors expressed herein do not necessarily state or reflect those of the United States government or any agency thereof. 


\title{
Leveraging Benefits Attributable to Centers within the Industrial Assessment Center Program
}

\author{
Michaela M. Martin \\ Bruce E. Tonn \\ Oak Ridge National Laboratory \\ Susan M. Schexnayder \\ University of Tennessee-Knoxville
}

February 2002

Prepared for

U.S. Department of Energy

Office of Industrial Technologies

\author{
Prepared by \\ OAK RIDGE NATIONAL LABORATORY \\ P.O. Box 2008 \\ Oak Ridge, Tennessee 37831-6285 \\ managed by \\ UT-Battelle, LLC \\ for the \\ U.S. DEPARTMENT OF ENERGY \\ under contract DE-AC05-00OR22725
}




\title{
CONTENTS
}

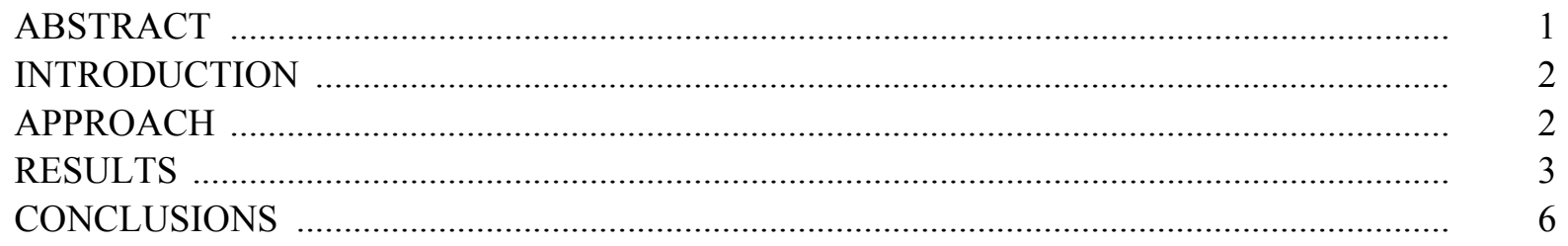

\begin{abstract}
The purpose of the research reported here was to assess the leveraging benefits attributable to the U.S. Department of Energy's (DOE's) Industrial Assessment Center (IAC) Program. The term leveraging as used in this study refers to any additional support received by a university-based, IAC-sponsored center that the center would not have received had the IAC Program not been in place. Twenty-two IACs provided information about 120 leveraging activities over the 1997-2001 period. IAC directors indicated that the support for 115 of these projects was linked to the existence of DOE's IAC Program and the experience gained from their participation in the program. Ninety-three of the IAC-influenced projects were quantified, for a monetary value of $\$ 5,948,931$. The average annual leveraged support was $\$ 1,189,786$ over the time frame examined. Typical contributors of leveraged support were state governments, utilities, industry, universities, and other DOE and federal agencies. Most of the support was provided to conduct assessments outside of IAC Program criteria (e.g., assessments of government buildings or large manufacturing plants). Significant leveraged support was also provided to IACs for educational activities - such as workshops, seminars, and training - and for miscellaneous energy-related technical projects.
\end{abstract}




\section{INTRODUCTION}

The U.S. Department of Energy's (DOE's) Industrial Assessment Center (IAC) Program provides financial support to many universities to establish IACs to train students in conducting free energy, waste, and productivity assessments for industrial firms. Currently, the program supports 26 university-based IACs. Each center is required to spend at least 25 days per year conducting assessments. Benefits attributable to the IAC Program are numerous. For example, firms receiving assessments (referred to as clients in this report) benefit by saving energy, reducing energy costs, reducing waste, and enhancing productivity. Other benefits of the IAC Program include alumni who go on to have careers in the energy field and IAC Program web sites that provide energy assessment and related technical information to users in many different sectors throughout the United States.

The purpose of this research project was to assess the leveraging benefits attributable to the IAC Program. In this study, the term leveraging refers to support received by DOE IAC-sponsored centers in excess of the core funding from DOE for activities beyond the centers' basic mission of conducting assessments. ${ }^{1}$ Such support would not have occurred if the base IAC sponsorships had not been in place. In addition to the assessment of leveraging benefits, the research reported here may serve to develop a better understanding of how IACs can leverage DOE funding to build larger and more diverse energy programs.

The next section discusses our approach to assessing leveraging benefits enjoyed by the IACs. The third section presents our assessment results. This short report concludes with several observations and recommendations.

\section{APPROACH}

A phone survey was conducted with IAC directors in the spring and summer of 2001 to collect information on leveraging activities pursued by their centers during the years 1997-2001. Twentytwo IAC directors representing the universities listed in Table 1 responded to the phone survey. Not participating in the interview process were directors from four schools. With 26 centers in operation in 2001 , this represents a response rate of $84.6 \%$.

Table 1. IACs participating in 2001 survey on leveraging benefits

\begin{tabular}{|c|c|c|}
\hline \multicolumn{2}{|l|}{ Participating IACs } & \multirow{2}{*}{$\begin{array}{l}\text { Nonparticipating IACs } \\
\text { Arizona State }\end{array}$} \\
\hline Bradley & Oklahoma State & \\
\hline Colorado State & Oregon State & Lehigh $^{a}$ \\
\hline Florida & San Diego State & Louisiana-Lafayette $^{a}$ \\
\hline Georgia Tech & San Francisco State & 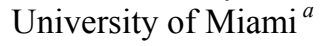 \\
\hline Illinois-Chicago $^{a}$ & Syracuse $^{a}$ & \\
\hline Iowa State & Texas A\&M & \\
\hline Loyola Marymount $^{a}$ & Texas-Arlington $^{a}$ & \\
\hline Massachusetts & University of Dayton & \\
\hline Michigan & $\mathrm{Utah}^{a}$ & \\
\hline Mississippi State & West Virginia & \\
\hline North Carolina State & Wisconsin-Milwaukee & \\
\hline
\end{tabular}

${ }^{a}$ New IAC established in 2001.

\footnotetext{
${ }^{1}$ Future research efforts will address leveraging benefits generated by IAC clients, alumni, and web site users.
} 
Each interview lasted about 20 minutes. Each director was asked to explain the purpose of each leveraging activity and who supported the activity. Also recorded were descriptions of the activity; the purpose, type, and value of the support; the dates the support covered; and the likelihood that the university would have received the support absent the IAC.

\section{RESULTS}

From the 22 IACs participating in this study, the survey collected information on 120 leveraging activities covering the period from 1997 through 2001. Of the 120 leveraged projects, directors indicated that it was "likely" to "extremely likely" that the support for 115 was due to the existence of the IAC Program and the experience gained from their participation in the program.

The IAC directors quantified leveraging benefits for 93 of these IAC-influenced projects. The total monetary value of these projects is $\$ 5,948,931$. Over the 5-year period addressed by this study, this works out to an annual average leveraging monetary benefit of approximately $\$ 1,189,786$ (Fig. 1).

Several centers contributed to the large influx of leveraged funds identified in 1997, with most of the funds designated for additional assessments, technical assistance, and specialized research. These centers were Georgia Tech, Oregon State, Oklahoma State, the University of Dayton, and the University of Massachusetts. During 1997, Oklahoma State received $\$ 500,000$ from oil overcharge funds to develop energy conservation plans

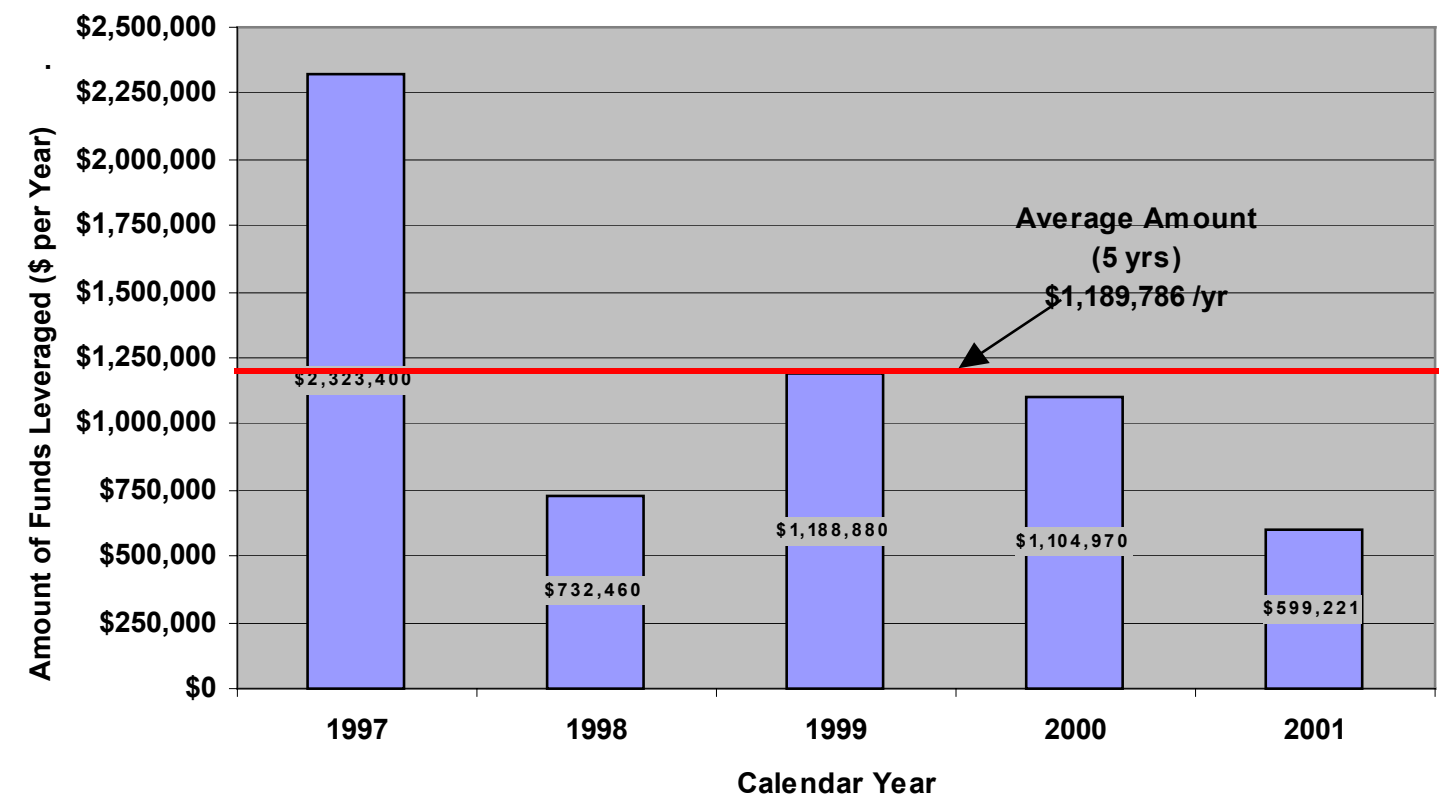

Fig. 1. Annual IAC-influenced leveraged funds, 1997-2001.
Table 2. Summary of impact of leveraged activities in 22 IACs, 1997-2001

\begin{tabular}{|c|c|}
\hline Total number of leveraged projects ............. & 120 \\
\hline $\begin{array}{l}\text { Projects leveraged as result of IAC } \\
\text { program at university }\end{array}$ & \\
\hline 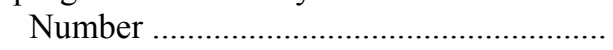 & 115 \\
\hline$\%$ of total & $96 \%$ \\
\hline Total value of 93 leveraged projects .......... & $\$ 5.9 \mathrm{M}$ \\
\hline
\end{tabular}


for 125 companies. The centers at Oregon State and the University of Massachusetts each received $\$ 125,000$ to perform energy assessments or provide additional technical assistance, while Georgia Tech received $\$ 200,000$ from local industry and $\$ 500,000$ from the state of Georgia for similar assessment-related activities. Finally, the center at the University of Dayton received a total of $\$ 335,000$ in funding from non-IAC DOE sources, industry, and the state of Ohio for research projects on compression improvements and fiscal incentives for "green" businesses. Additional details on typical funding sources and leveraging activities for the 5-year period studied are provided in Tables 3 and 4.

The 5-year snapshot provided by Fig. 1 indicates that there may be considerable fluctuation in new leveraging funds from year to year. This is certainly true; however, a closer look at the project information provided by the centers reveals that the contract periods associated with the new funds are not necessarily limited to one year. Therefore, some fluctuation should be anticipated as centers land large contracts, complete the work over an extended period of time (i.e., 2-3 years), and then seek additional funding opportunities.

A breakdown of the leveraging activities by contributors of leveraging support is found in Table 3 . Similarly, Table 4 breaks down the activities by type of collaboration. Several important observations that can be made about these results:

- The states are major contributors. The biggest single leveraging award was given to Georgia Tech by the state of Georgia — \$2.5 million awarded in 1997 and distributed in \$500,000 increments over 5 years through 2001 - to perform plantwide assessments, provide technical assistance, and work on special projects. In general, the states provided funds for assessments and educational activities, such as workshops.

Table 3. Contributors of IAC-influenced leveraging support, 1997-2001

\begin{tabular}{lcc}
\hline \multicolumn{1}{c}{ Contributors } & $\begin{array}{c}\text { Number of } \\
\text { projects }^{a}\end{array}$ & $\begin{array}{c}\text { Estimated total } \\
\text { value of projects } \\
(1997-2001)\end{array}$ \\
\hline States (energy and environmental offices) & 19 & $\$ 3,025,700$ \\
Industry & 13 & $\$ 1,079,250$ \\
Universities & 11 & $\$ 586,500$ \\
Other DOE offices & 15 & $\$ 511,948$ \\
Other federal agencies & 11 & $\$ 192,173$ \\
Undetermined type of sponsor & 3 & $\$ 190,000$ \\
Municipalities & 3 & $\$ 183,000$ \\
Utilities & 14 & $\$ 173,300$ \\
Energy service organizations & 3 & $\$ 3,560$ \\
Nonprofit organizations & 1 & $\$ 3,500$ \\
\hline \multicolumn{1}{c}{ All contributors } & 93 & $\$ 5,948,931$ \\
\hline
\end{tabular}

${ }^{a}$ Includes only the 93 projects for which monetary value information was provided. 
Table 4. Types of activities funded by IAC-influenced leveraging support, 1997-2001

\begin{tabular}{lcc}
\hline \multicolumn{1}{c}{ Type of activity funded } & $\begin{array}{c}\text { Number of } \\
\text { projects }^{a}\end{array}$ & $\begin{array}{c}\text { Estimated total } \\
\text { value of projects } \\
(1997-2001)\end{array}$ \\
\hline Conducting assessments beyond base contract & 31 & $\$ 3,525,771$ \\
Miscellaneous projects (e.g., research) & 17 & $\$ 1,516,200$ \\
Supporting IAC operation & 14 & $\$ 666,300$ \\
Educational service (e.g., workshop) & 8 & $\$ 87,700$ \\
Outreach and client identification & 16 & $\$ 78,380$ \\
Technical assistance & 2 & $\$ 41,500$ \\
Collaboration on assessments & 5 & $\$ 33,080$ \\
\hline \multicolumn{1}{c}{ All types } & 93 & $\$ 5,948,931$ \\
\hline
\end{tabular}

${ }^{a}$ Includes only the 93 projects for which monetary value information was provided.

- Universities themselves provide support to the IACs. The most typical types of support are reductions in indirect cost rates, computers, and scholarships for students taking part in IAC activities.

- Overall, the IACs worked well with utilities and industry. Utilities typically provided in-kind support to identify new clients for the IACs. Industry sponsored numerous additional assessments and educational activities.

- Other DOE programs and other federal agencies provided significant support to the IACs. Among DOE contributors was the Federal Energy Management Program, which provided funds for assessments of federal industrial facilities and training for federal energy managers. Other federal agencies providing funds included the Army National Guard, the General Services Administration, the U.S. Environmental Protection Agency, the National Park Service, and the U.S. Department of Transportation. Most of the funding was to support additional assessments and special projects.

- The large number of leveraged assessment projects indicates that assessment expertise developed by IACs is transferable and in high demand in a number of other contexts, including state and federal buildings and large manufacturing plants.

- The large number of educational service activities - which include workshops, seminars, and special training sessions - indicates that there is a demand for the sharing of the knowledge of the IAC staff. This educational mission is wholly appropriate for university-based IACs.

- The large number of miscellaneous projects indicates that general IAC expertise in energy and production technologies is transferable and in high demand for all sorts of specialized applications (e.g., die casting, foundry sand reclamation, research on the effects of furnace designs, and metal casting). 
The overall value of the leveraged activities of nearly $\$ 6$ million can be considered a conservative estimate of the overall leveraging benefits of the IAC Program for several reasons. First, the data collection exercise did not include 12 IACs that did not receive contract extensions during the recent recompetition. It is very likely that some of these former centers received leveraged support during the years 1997-2000. Since several of those programs had been in existence for many years, it can be argued that their leveraging activities would have resembled the activities for those IACs that were included in this study and probably would have contributed additional funds to the overall total.

Second, the IAC directors did not provide estimates of monetary value for 26 projects. While many of these activities were limited and provided only small, intangible benefits, such as helping with IAC outreach activities, several activities may have provided substantial financial benefits if quantified, such as universities' lowering indirect cost rates on funds received from DOE to support the centers.

Third, this project did not rigorously pursue how IAC clients, alumni, and web site users might have leveraged the services or training received from interactions with their IACs to implement energy saving, waste reduction, and productivity enhancement measures. This topic was broached with a few IAC directors during the interview process, but it soon became clear that they did not keep track of this type of information. Leveraging by clients, alumni, and web site users will be addressed by the next phase of research on the benefits of the IAC Program.

Lastly, as the eight new centers mature, it is expected that their ability to leverage DOE-IAC funds will improve, resulting in an overall increase of dollars leveraged.

\section{CONCLUSIONS}

University-based centers are successfully leveraging their DOE IAC-supported activities to increase the scale and scope of their programs. On average, with $\$ 3.9$ million per year in DOE IAC funding (assuming that each of the 26 current centers received $\$ 150,000$ per year), centers were able to leverage an additional $\$ 1.19$ million, or 30\%, in funds per year over the past 5 years. With the additional funding generated through leveraging, the IACs are providing value-added to states, utilities, industry, and other DOE and federal programs. Most of the support is for assessments of government buildings and large manufacturing plants-i.e., for assessment work beyond the basic criteria of the IAC Program. Because the evidence strongly suggests that centers are heavily involved in leveraging activities, it is highly recommended that DOE implement a means for continued tracking of such activities.

This study did not attempt to address in detail the leveraging benefits attributed to IAC clients, alumni, and web site users. Instead, the focus was purely on the leveraging activities generated by the centers themselves as they expanded the scope of their individual services and programs. Leveraging benefits accrued by the clients, alumni, and web site users will be addressed in future evaluation efforts. 


\section{INTERNAL DISTRIBUTION}

1. L. G. Berry

2. M. A. Brown

3. T. R. Curlee

4. S. Das

5. J. F. Eisenberg

6. P. J. Hughes

7. G. K. Jacobs

\author{
8. M. A. Martin \\ 9. R. L. Schmoyer \\ 10. M. Schweitzer \\ 11. B. E. Tonn \\ 12. ORNL Central Research Library \\ 13. Office of Technical Information \\ and Classification
}

\section{EXTERNAL DISTRIBUTION}

14. William Clark (wjclark@itemdiv.org)

15. Kenneth Friedman (kenneth.friedmann@ee.doe.gov)

16. Sandy Glatt (sandy.glatt@ee.doe.gov)

17. Andrew Gluck (gluckandrew@home.com)

18. Michael Muller (muller@camp.rutgers.edu)

19. Peggy Podolak (peggy.podolak@ee.doe.gov)

20. Susan Schexnayder (schexnayder@utk.edu) 